\title{
A New Type of Strong Metal-Support Interaction Caused by Antimony Species
}

\author{
A. Benhmid ${ }^{1 *}$, K. El Ttaib1', K. Edbey¹, V. N. Kalevaru², B. Lücke² \\ ${ }^{1}$ Chemistry Department, Benghazi University, Benghazi, Libya \\ ${ }^{2}$ Leibniz Institute für Katalyse e.V. an der Universitat Rostock, Rostock, Germany \\ Email:*abdelhadi.benhmid@uob.edu.ly
}

How to cite this paper: Benhmid, A., El Ttaib, K., Edbey, K., Kalevaru, V.N. and Lücke, B. (2020) A New Type of Strong Metal-Support Interaction Caused by Antimony Species. Open Journal of Metal, 10, 17-33.

https://doi.org/10.4236/ojmetal.2020.102002

Received: May 25, 2020

Accepted: June 27, 2020

Published: June 30, 2020

Copyright $\odot 2020$ by author(s) and Scientific Research Publishing Inc. This work is licensed under the Creative Commons Attribution International License (CC BY 4.0).

http://creativecommons.org/licenses/by/4.0/ (c) (i) Open Access

\begin{abstract}
Interactions between metals and supports are of fundamental interest in heterogeneous catalysis, Noble metal particles supported on transition metal oxides (TMO) may undergo a so-called strong metal-support interaction via encapsulation. This perspective addresses catalytic properties of the metal catalysts in the SMSI state which can be explained on the basis of complementary studies. The electronic geometric and bifunctional effects originating from strong metal-support interactions (SMSI) that are responsible for the catalyst's activity, selectivity, and stability are key factors that determine performance. A series of Pd-Sb supported on different metal oxide (i.e. $\mathrm{SiO}_{2}, \gamma-\mathrm{Al}_{2} \mathrm{O}_{3}, \mathrm{TiO}_{2}$, and $\mathrm{ZrO}_{2}$ ) were prepared by the impregnation method. The catalysts were characterized by $\mathrm{N}_{2}$ adsorption (BET-SA and pore size distribution), TEM (transmission electron microscope), TPR (temperature-programmed reduction), CO-chemisorption, the structural characterization of Pd (dispersity, surface area), interaction between $\mathrm{Pd}$ and $\mathrm{Sb}_{2} \mathrm{O}_{3}$ and also the influence of the nature of the support were investigated. $\mathrm{SiO}_{2}$ supported $\mathrm{Pd}$ catalyst exhibited the highest surface area $\left(192.6 \mathrm{~m}^{2} / \mathrm{g}\right)$ and pore volume $\left(0.542 \mathrm{~cm}^{3} / \mathrm{g}\right)$ compared to the other supported oxides catalysts. The electron micrographs of these catalysts showed a narrow size particle distribution of $\mathrm{Pd}$, but with varying sizes which in the range from 1 to $10 \mathrm{~nm}$, depending on the type of support used. The results show almost completely suppressed of $\mathrm{CO}$ chemisorption when the catalysts were subjected to high temperature reduction (HTR), this suppression was overcome by oxidation of a reduced $\mathrm{Pd} / \mathrm{MeOx}$ catalysts followed by re-reduction in hydrogen at $453 \mathrm{~K}$ low temperature reduction (LTR), almost completely restored the normal chemisorptive properties of the catalysts, this suppression was attributed by SbOx species by a typical SMSI effect as known for other reducible supports such as $\mathrm{TiO}_{2}, \mathrm{ZrO}_{2}, \mathrm{CeO}_{2}$, and $\mathrm{Nb}_{2} \mathrm{O}_{5}$.
\end{abstract}




\section{Keywords}

BET-SA and Pore Size Distribution, TEM, SMSI Effect, Metal Oxide Supports, TPR, CO-Chemisorption, SbOx Species

\section{Introduction}

The catalysis is considered one of the most important research areas in chemistry, related fields, industry and technology which provides new material and conditions to reduce the cost, as well as time and besides that looking for a new and alternative solution for treatment of wastes, moreover catalytic materials have massive contribution to the environmental impact which influence in cleaning the air from toxic gases such as $\mathrm{CO}$ and $\mathrm{NO}_{\mathrm{x}}$, water wastes, etc.

At the end of 1970s Tauster and coworkers are connected to the strong metal-support interaction (SMSI), they perceived that the adsorption of $\mathrm{H}_{2}$ and $\mathrm{CO}$ to descend after some treatment of oxide-supported noble metal catalysts, most apparently for Pt supported on $\mathrm{TiO}_{2}$ [1] [2]. Modern advanced electron spectroscopy studies showed that the metal confined which is now regarded as the major demonstration of strong metal-support interaction (SMSI) [3] [4]. SMSI is sometimes used in a more general sense by including support effects on metal dispersion, spatial distribution, and particle shape. Although the $\mathrm{Pt} / \mathrm{TiO}_{2}$ system remains the classic example of SMSI via encapsulation, several other combinations of reducible transition metal oxides (TMO) and metals have shown similar behavior [5] [6] [7] [8]. Despite enormous efforts to directly visualize the encapsulation process, the precise mechanism of encapsulation remains unknown. Thermodynamic considerations favor oxide spillover onto the metal surface rather than migration through the metal particle and subsequent segregation to the surface. For the past 20 years, a large number of publications have dealt with different aspects of the SMSI effect [1]. This research effort may easily be justified in terms of a fundamental understanding of such a special phenomenon, but also because of its implications in the design of specific preparation, characterisation, or catalytic applications of the metal/support system exhibiting this effect.

Since the very first studies [2] [7] [9], the characteristics of the SMSI effect could be established in a rather precise way. Typically associated with reducible supports, it is characterised by the following features: 1) the catalyst reduced at low temperature show a conventional chemical behaviour, 2) Upon increasing $\mathrm{T}_{\text {redn }}$, the chemisorption capability of the dispersed metal phase against the classic probe molecules like $\mathrm{H}_{2}$ or $\mathrm{CO}$ is heavily disturbed (SMSI state). Likewise, substantial modifications of its catalytic behaviour are observed [7]. The phenomena are reversible, i.e. the re-oxidation at an appropriate temperature followed by a mild re-reduction treatment allows recovering the catalyst from SMSI state. 
In the decade of 1980 , the majority of the studies dealing with this effect were focused on $\mathrm{M} / \mathrm{TiO}_{2}$ systems [7]. The experimental conditions allowing both the induction of the SMSI state and the recovery from it were soon established. Regarding the onset of the effect, reduction, usually with flowing hydrogen, at $773 \mathrm{~K}$, may be considered as a typical treatment. As far as the regeneration of the catalyst is considered, re-oxidation in a flow of $\mathrm{O}_{2}$ at $773 \mathrm{~K}$, followed by reduction at $\mathrm{T} \leq 573 \mathrm{~K}$, is generally accepted to induce the reversion of the phenomenon.

SMSI plays a critical role in determining catalytic activity and stability. Gold particles supported on metal oxides, such as $\mathrm{TiO}_{2}, \mathrm{Fe}_{2} \mathrm{O}_{3}$, and $\mathrm{CeO}_{2}$ possess significant oxidation activity when compared to unsupported gold particles [10]. SMSI was originally explained as an electron transfer between the support and the metal [11], or by the formation of intermediate phases [12]. Current thinking with respect to the fundamental concepts underlying strong metal-support interactions additionally attaches importance to interfacial and transport phenomena, together with charge redistribution during metal-support interface formation. SMSI gives rise to three major effects (electronic, geometric and bifunctional), as shown in Scheme 1. The change in the electronic properties of the metal catalyst originates from the strong interactions between the cluster and the oxide support [13] [14] [15]. The geometric effect originates from the physical covering of a thin layer of a reducible oxide species blocking active catalytic sites on the metal's surface [7] [16]-[24]. The bifunctional effect provides dual active sites at the perimeter between the metal and the support leading to significantly improved catalytic activity/selectivity. The reaction species can migrate or spillover either from metal or support to the boundary or edge where the chemical reactions occur. Recognition of the importance of SMSI has attracted many researchers in diverse heterogeneous catalytic applications such as chemical synthesis [25] water splitting [26] and environmental engineering [27] [28] [29] [30] [31].

The origin of SMSI was widely discussed. Two major factors were considered [7]. For some authors, the perturbations associated with the electronic interaction

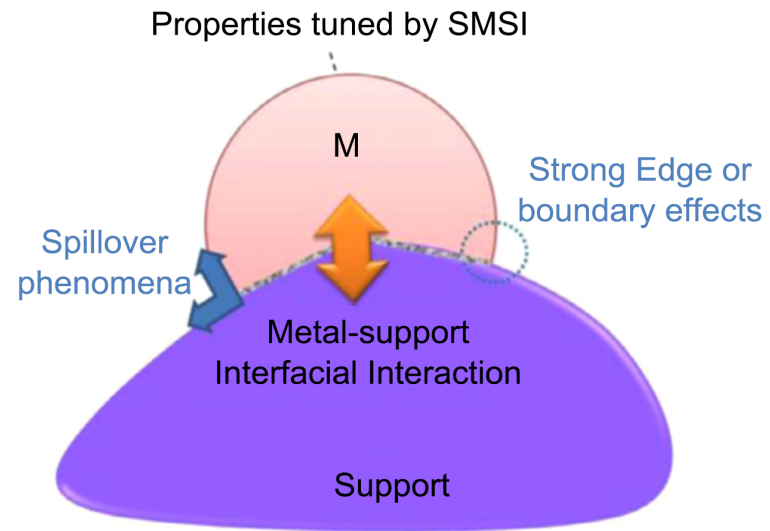

Scheme 1. A model of a supported metal particle, illustrating the effects of metal-support interfacial interactions [32]. 
occurring between the dispersed metal phase and the reduced oxide support would be the determined factor. For some others, the effect had a geometric origin, i.e. upon high temperature reduction; the metal particles would become partly covered by a thin layer of the reduced support, thus blocking the chemisorption active centres at the metal surface. Regarding the latter interpretation, a number of experimental techniques, and particularly high resolution electron microscope (HREM) [16] [33] [34] has clearly shown the occurrence of metal covering (decoration).

Though to a much lesser extent than titania, several other reducible oxides have also been investigated in relation to the SMSI effect. Such is the case of vanadia or niobia-based catalysts [7] [9]. Moreover, the SMSI effect has been reported to occur on $\mathrm{Pt} / \mathrm{SiO}_{2}$ and $\mathrm{Pd} / \mathrm{La}_{2} \mathrm{O}_{3}$ [35]. These two cases are particularly striking because the supports, $\mathrm{SiO}_{2}$ and $\mathrm{La}_{2} \mathrm{O}_{3}$ are generally considered to be hardly reducible oxides. On $\mathrm{Pt} / \mathrm{SiO}_{2}$, the metal deactivation effects start to be observed on the catalyst after $10 \mathrm{~h}$ at $823 \mathrm{~K}$, they becoming much stronger after a prolonged reduction treatment at $973 \mathrm{k}$. Severe reduction conditions are thus required to induce the effect [34].

The aim of the present study was to carry out $\mathrm{CO}-\mathrm{Chemisorption} \mathrm{of} \mathrm{Pd}-\mathrm{Sb} / \mathrm{MeOx}$ (to measure the dispersion of Palladium) and to check the SMSI phenomena.

\section{Experimental}

\subsection{Catalyst Preparation}

Preparation of catalysts involves mainly two steps as described below:

Step 1: Commercial $\mathrm{TiO}_{2}$ (anatase, Powder, Kronos, BET-SA-315 m²/g) was impregnated with aq. solution of $\mathrm{SbCl}_{3}$ (Alfa Produkte, Karlsruhe, Germany) by keeping $8 \mathrm{wt} \% \mathrm{Sb}$ with respect to the total amount of the catalyst and kept it aside for 1 hour followed by precipitation with $\left(\mathrm{NH}_{4}\right)_{2} \mathrm{SO}_{4}$ and kept at $70^{\circ} \mathrm{C}$ for 1 hour on a water bath. After cooling to room temperature the solution was neutralized with $25 \%$ ammonia (adjusted to $\mathrm{pH}$ of 7 ) and heated on the water bath for another hour. Afterwards the slurry was filtered and dried on a rota-vapor to remove excess water; the resulting solid mass was further dried in an oven at $120^{\circ} \mathrm{C}$ for $16 \mathrm{~h}$, followed by calcination at $400^{\circ} \mathrm{C}$ for $3 \mathrm{~h}$ in $\operatorname{air}(50 \mathrm{ml} / \mathrm{min})$.

Step 2: The above mentioned $\mathrm{Sb}$ impregnated $\mathrm{TiO}_{2}$ sample was again impregnated with desired amount of acidified aqueous solution of $\mathrm{PdCl}_{2}$ (99.8\%, Alfa Produkte, Karlsruhe, Germany) to get the desired amount of Pd (10 wt\%) the excess solvent was removed by rota vapor, and the sample was dried in an oven at $120^{\circ} \mathrm{C}$ for $16 \mathrm{~h}$. In a similar fashion, all of the catalysts were prepared using four different oxide supports such as $\mathrm{ZrO}_{2}, \mathrm{SiO}_{2}$, and $\gamma-\mathrm{Al}_{2} \mathrm{O}_{3}$. More details on catalyst preparation have been reported elsewhere [36]. The denotation and composition of different samples prepared are presented in Table 1. The composition of the materials was checked by inductively coupled plasma-optical emission spectrometry (ICP-OES), and the values were found to be close to the theoretical ones. 
Table 1. The denotation, composition, BET surface areas, and pore volumes of PdSb catalysts with different supports.

\begin{tabular}{cccc}
\hline Denotation & Catalyst composition & $\begin{array}{c}\text { Fresh BET-SA } \\
\left(\mathrm{m}^{2} / \mathrm{g}\right)\end{array}$ & $\begin{array}{c}\text { Catalysts pore } \\
\text { volume }\left(\mathrm{cm}^{3} / \mathrm{g}\right)\end{array}$ \\
\hline $10 \mathrm{Pd} 8 \mathrm{Sb} / \mathrm{TiO}_{2}$ & $10 \mathrm{wt} \% \mathrm{Pd}, 8 \mathrm{wt} \% \mathrm{Sb} / \mathrm{TiO}_{2}$ & 78.1 & 0.128 \\
$10 \mathrm{Pd} 8 \mathrm{Sb} / \mathrm{ZrO}_{2}$ & $10 \mathrm{wt} \% \mathrm{Pd}, 8 \mathrm{wt} \% \mathrm{Sb} / \mathrm{ZrO}_{2}$ & 46.6 & 0.108 \\
$10 \mathrm{Pd} 8 \mathrm{Sb} / \mathrm{SiO}_{2}$ & $10 \mathrm{wt} \% \mathrm{Pd}, 8 \mathrm{wt} \% \mathrm{Sb} / \mathrm{SiO}_{2}$ & 192.6 & 0.542 \\
$10 \mathrm{Pd} 8 \mathrm{Sb} / \gamma-\mathrm{Al}_{2} \mathrm{O}_{3}$ & $10 \mathrm{wt} \% \mathrm{Pd}, 8 \mathrm{wt} \% / \gamma-\mathrm{Al}_{2} \mathrm{O}_{3}$ & 98.8 & 0.211 \\
- & $\mathrm{Pure} \mathrm{TiO}_{2}$ & 315 & 0.273 \\
- & $\mathrm{Pure} \mathrm{ZrO}_{2}$ & 206 & 0.225 \\
- & $\mathrm{Pure} \mathrm{SiO}_{2}$ & 392 & 0.573 \\
- & ${\mathrm{Pure} \gamma-\mathrm{Al}_{2} \mathrm{O}_{3}}$ & 249 & 0.471 \\
\hline
\end{tabular}

Methods: TPR/ $\mathrm{H}_{2}$ up to $250^{\circ} \mathrm{C}$ (Low Temperature Reduction) to prepare Pd particles.

$\mathrm{TPR} / \mathrm{H}_{2}$ up to $350^{\circ} \mathrm{C}$ (High Temperature Reduction) to check a SMSI effect by antimony.

$\mathrm{CO}$ pulse chemisorption at r.t. after TPR and subsequent elution with a $\mathrm{He}$ flows at final temperature.

\subsection{Characterization of Catalysts}

The BET surface areas and pore size distribution of the catalysts were determined using a Micromeritics Gemini III 2375 instrument by $\mathrm{N}_{2}$ physisorption at $-196^{\circ} \mathrm{C}$. Before the measurements, the known amount of catalyst was evacuated for $2 \mathrm{~h}$ at $150^{\circ} \mathrm{C}$ to remove physically adsorbed water.

Samples for transmission electron microscopy (TEM) were prepared by depositing the sample on a copper grid (300 mesh) coated with lacy carbon film. TEM analysis was performed using a CM-20 microscope (twin) (Philips, The Netherlands) at $200 \mathrm{kV}$ with EDAX PV 9900.

The catalysts were characterized using (AMI-1 (Zeton/Altamira)), TCD.

Catalyst pretreatment: calcination in air at $300^{\circ} \mathrm{C}$ for $2 \mathrm{~h}$, catalyst sample weight 0.12 to $0.14 \mathrm{~g}$.

$5.1 \% \mathrm{H}_{2} / \mathrm{Ar}$, flow rate $50 \mathrm{ml} / \mathrm{min}, 10 \mathrm{~K} / \mathrm{min}$, calibrated by $500 \mu \mathrm{l} \mathrm{Ar}$-Pulses into $5.1 \% \mathrm{H}_{2} / \mathrm{Ar}$.

$500 \mu \mathrm{l}$ pulses of $19.7 \% \mathrm{CO} / \mathrm{He}$ into He flow $50 \mathrm{ml} / \mathrm{min}$.

\section{Results and Discussion}

\subsection{BET Surface Areas and Pore Size Distribution}

BET surface areas and pore volumes of the fresh catalysts prepared with four different supports are presented in Table 1. Of the four supports used, the surface area of the $\mathrm{TiO}_{2}$ (anatase)-supported catalyst decreased drastically (from 315 to 
$78 \mathrm{~m}^{2} / \mathrm{g}$ ) after impregnation of both $\mathrm{Sb}(8 \mathrm{wt} \%)$ and $\mathrm{Pd}(10 \mathrm{wt} \%)$. However, no such drastic decrease in surface area was seen in the catalysts prepared with other supports. These decreases in surface area and pore volume after the deposition of $\mathrm{Sb}$ and $\mathrm{Pd}$ is due mainly to penetration of dispersed $\mathrm{Pd}$ and $\mathrm{Sb}$ species into the pores of the support, as well as to solid-state reactions between the dispersed components and the support. But the extent of decrease in surface areas depends on the nature of the support applied. Table 1 shows that of all of the supports studied in this series, $\mathrm{SiO}_{2}$-supported $\mathrm{Pd}$ catalyst exhibited the highest surface area $\left(193 \mathrm{~m}^{2} / \mathrm{g}\right)$ and pore volume $\left(0.542 \mathrm{~cm}^{3} / \mathrm{g}\right) ; \mathrm{ZrO}_{2}$ had the lowest surface area $\left(47 \mathrm{~m}^{2} / \mathrm{g}\right)$ and pore volume $\left(0.107 \mathrm{~cm}^{3} / \mathrm{g}\right)$.

Pore size distributions of fresh catalysts are portrayed in Figure 1. These figures clearly show that all of the catalysts exhibited unimodal pore volume distribution. Although all of these catalysts had a unimodal distribution, they had some differences, especially in terms of pore size and distribution (Figure 1). Such differences in pore size are due to differences in the type of oxide supports applied and their varying surface areas. The catalysts prepared with reducible supports $\left(\mathrm{TiO}_{2}, \mathrm{ZrO}_{2}\right)$ with low surface areas. showed a narrow distribution in the range of ca. 20 - $50 \AA$ with a dominant pore diameter around $35 \AA$. On the other hand, the catalysts with high surface areas $\left(\mathrm{SiO}_{2}, \gamma-\mathrm{Al}_{2} \mathrm{O}_{3}\right)$ displayed a considerably broader range of pore size distribution, from ca. 25 - $150 \AA$, with dominant pore diameters around $85 \AA\left(\mathrm{SiO}_{2}\right)$ and $60 \AA\left(\gamma-\mathrm{Al}_{2} \mathrm{O}_{3}\right)$, respectively.

\subsection{Transmission Electron Microscopy (TEM)}

Electron micrographs of the fresh (activated) $10 \% \mathrm{Pd} 8 \% \mathrm{Sb}$ catalysts with different supports are depicted in Figure 2. All of these catalysts showed a narrow particle size distribution of $\mathrm{Pd}$, but with varying sizes, depend on the type of support used. It can be seen from Figure 2 (a) that the fresh $\mathrm{TiO}_{2}$-supported catalyst exhibited relatively larger Pd particles compared with the other supports.

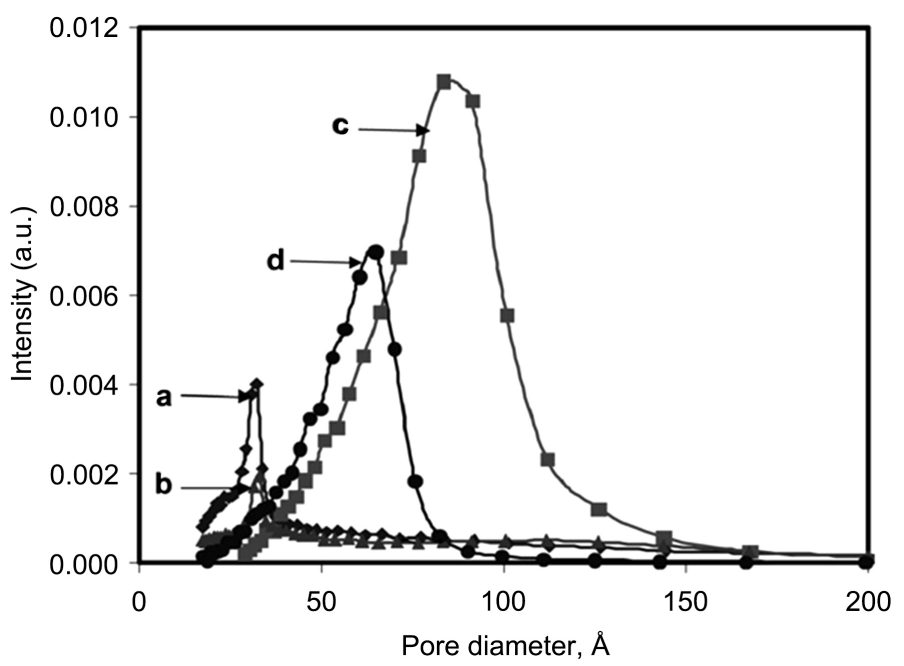

Figure 1. Pore volume distribution of the fresh $10 \% \mathrm{Pd} 8 \% \mathrm{Sb}$ catalysts with different supports (a: $\mathrm{TiO}_{2} ; \mathrm{b}: \mathrm{ZrO}_{2} ; \mathrm{c}: \mathrm{SiO}_{2} ; \mathrm{d}: \gamma-\mathrm{Al}_{2} \mathrm{O}_{3}$ ). 

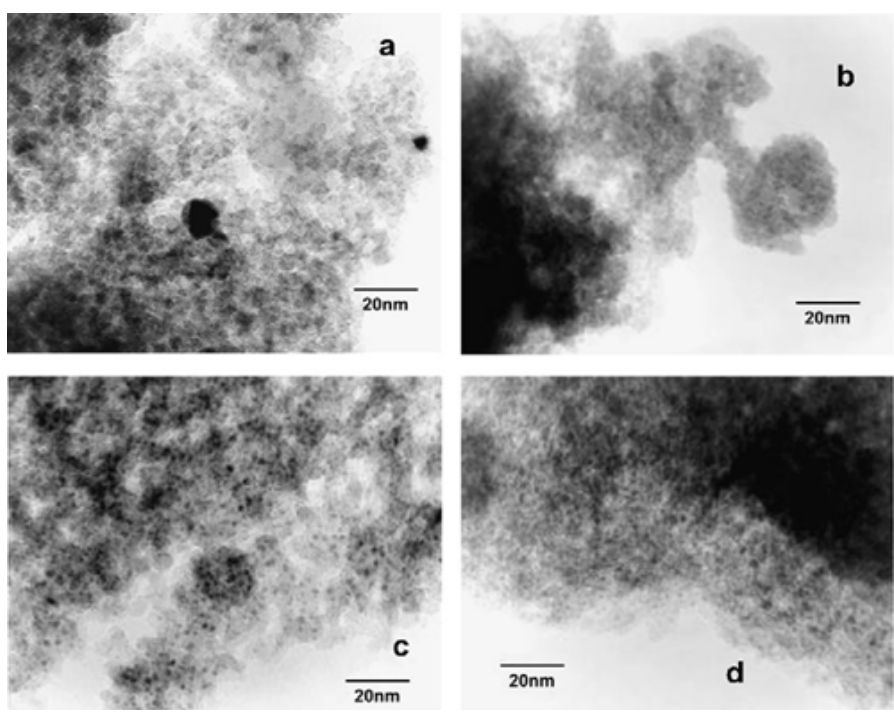

Figure 2. Electron micrographs of the (a) fresh $10 \% \mathrm{Pd} 8 \% \mathrm{Sb}$ catalysts with different supports [37].

The Pd particles on $\mathrm{TiO}_{2}$ support were spherical shaped and ranged in size from 1 to $10 \mathrm{~nm}$. Shen et al. [38] reported from their TEM analysis on $\mathrm{TiO}_{2}$-supported Pd catalysts with different Pd loadings that Pd particles are hemispherical in shape with a narrow size distribution of $4-20 \mathrm{~nm}$, which are fixed in the welldeveloped planes of $\mathrm{TiO}_{2}$. As a result of such matching, these authors suggested that the support structure could stabilize Pd particles and favour strong metal-support interaction. In the case of fresh $\mathrm{SiO}_{2}$-supported catalyst (Figure 2(c)), the Pd particles are uniformly distributed on the support with size ranging from 2 to $4 \mathrm{~nm}$ and shape again nearly spherical These results are in agreement with those reported by Lyubovsky et al. [39]. $\mathrm{ZrO}_{2}-$ and $\gamma-\mathrm{Al}_{2} \mathrm{O}_{3}$-supported catalysts (Figure 2(b) and Figure 2(d)) showed Pd morphology similar to that of $\mathrm{TiO}_{2-}$ and $\mathrm{SiO}_{2}$-supported ones but with smaller Pd particles. Among the four fresh solids investigated, the $\mathrm{ZrO}_{2}$-supported catalyst (Figure 2(b)) exhibited very small Pd particles (1.5 - $2 \mathrm{~nm}$ ) with a narrow size distribution, more or less comparable to the $\gamma-\mathrm{Al}_{2} \mathrm{O}_{3}$-supported solid. The decreasing order of Pd particle size in these fresh $10 \% \mathrm{Pd} 8 \% \mathrm{Sb}$ catalysts over the different supports is as follows:

$$
\mathrm{TiO}_{2}>\mathrm{SiO}_{2}>\mathrm{ZrO}_{2} \sim \mathrm{Al}_{2} \mathrm{O}_{3}
$$

\subsection{Pre-Investigation}

TPR of $\mathrm{Sb}_{2} \mathrm{O}_{3}$ : The TPR plot shown in Figure 3 revealed that the reduction of unsupported $\mathrm{Sb}_{2} \mathrm{O}_{3}$ only starts at about $480^{\circ} \mathrm{C}$. The stepwise reduction to $\mathrm{Sb}(0)$ is not finished at $800^{\circ} \mathrm{C}$ and the shoulder at the high temperature flank is not a real peak but it is due to the end of the temperature ramp. Presumably, the reduction $\mathrm{Sb}_{2} \mathrm{O}_{3}$ to $\mathrm{Sb}$ occurs stepwise, e.g. $\mathrm{Sb}_{6} \mathrm{O}_{13}$ of could be formed as intermediate.

TPR of $\mathrm{Sb}_{2} \mathrm{O}_{3} / \mathrm{SiO}_{2}$ : the reduction of supported $\mathrm{Sb}_{2} \mathrm{O}_{3}$ did not start at lower temperature but rather at slightly higher temperature $\left(\mathrm{ca} .500^{\circ} \mathrm{C}\right)$ as can be seen in Figure 4. 


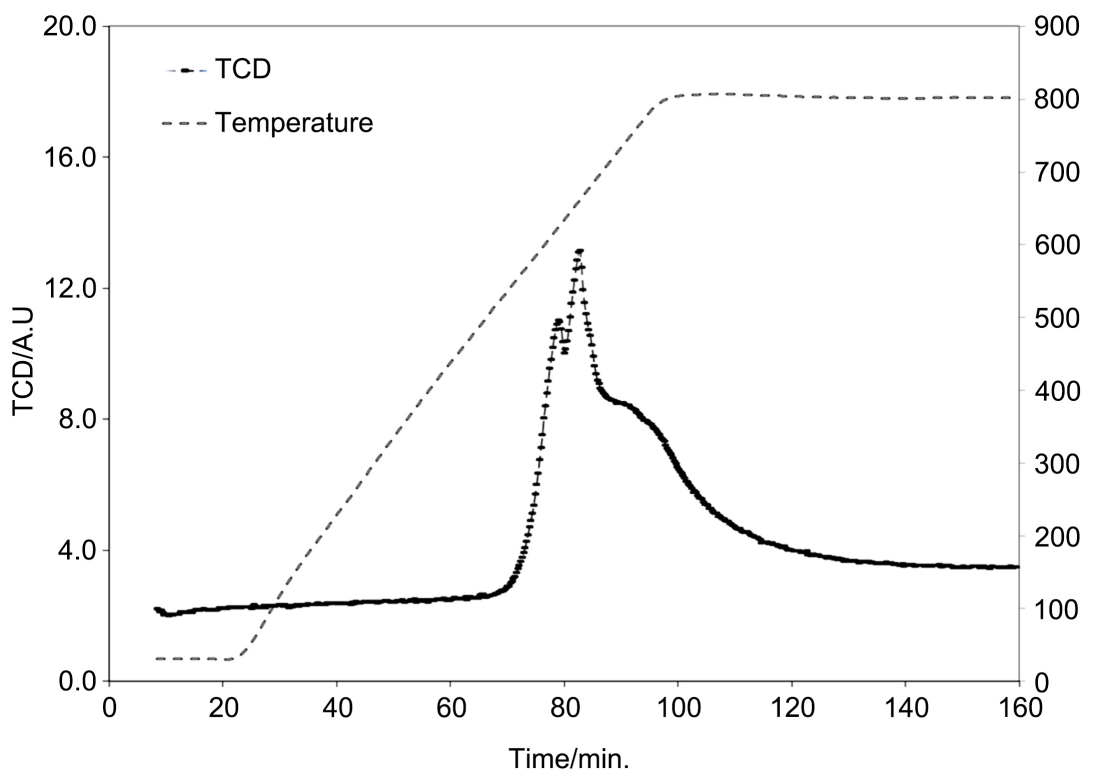

Figure 3. TPR of $\mathrm{Sb}_{2} \mathrm{O}_{3}$.

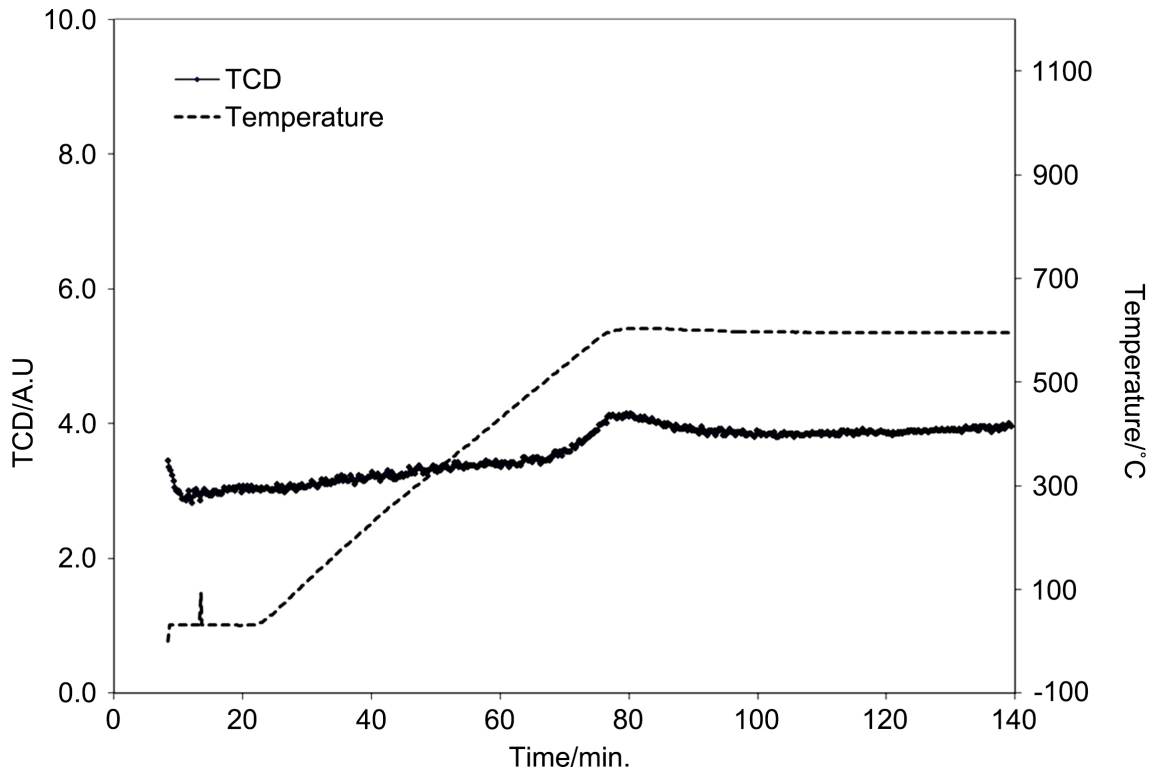

Figure 4. TPR of $\mathrm{Sb}_{2} \mathrm{O}_{3} / \mathrm{SiO}_{2}$.

\subsection{Combined TPR and CO Chemisorption}

High temperature reduction (HTR): Figure 5 shows the plot obtained with $\mathrm{Pd} / \mathrm{Sb}_{2} \mathrm{O}_{3} / \mathrm{Al}_{2} \mathrm{O}_{3}$. The first negative peak is due to $\mathrm{H}_{2}$ desorption by decomposition $\beta$-Pd hydride. That means that a portion of $\mathrm{Pd}(\mathrm{II})$ is already reduced to metallic Pd at room temperature (r.t.) during the isothermal segment of the TPR procedure which is not monitored. It is well known that metallic Pd absorbs $\mathrm{H}_{2}$ into its bulk forming $\beta$-Pd hydride. The decomposition peak is superimposed by the further reduction of $\mathrm{Pd}(\mathrm{II}) .3$ peaks in the temperature range up to ca. $250^{\circ} \mathrm{C}$ point to the reduction of different $\mathrm{Pd}(\mathrm{II})$ species or Pd(II) species of different size. The additional peak with maximum at the final temperature should be at- 
tributed to a reduction of $\mathrm{Sb}_{2} \mathrm{O}_{3}$ since reduction of supported $\mathrm{PdO}$ or $\mathrm{PdCl}_{2}$ is usually finished at temperatures below $300^{\circ} \mathrm{C}$. Probably, hydrogen activated on $\mathrm{Pd}$ reduces $\mathrm{Sb}(\mathrm{III})$ at lower temperature than in case of the Pd free sample. The peak maximum at final temperature is an apparent maximum again, because the applied isothermal holds in the TPR procedure.

A similar HTR-plot was obtained with the $\mathrm{Pd} / \mathrm{Sb}_{2} \mathrm{O}_{3} / \mathrm{ZrO}_{2}$ sample (Figure 6). $\mathrm{Pd}$ hydride decomposition was very distinctive. Again a reduction of $\mathrm{Sb}_{2} \mathrm{O}_{3}$ besides $\mathrm{Pd}(\mathrm{II})$ was observed.

The $\beta$-Pd hydride decomposition is completely superimposed by the $\mathrm{H}_{2}$ consumption in the case of the $\mathrm{Pd} / \mathrm{Sb}_{2} \mathrm{O}_{3} / \mathrm{TiO}_{2}$ sample (Figure 7).

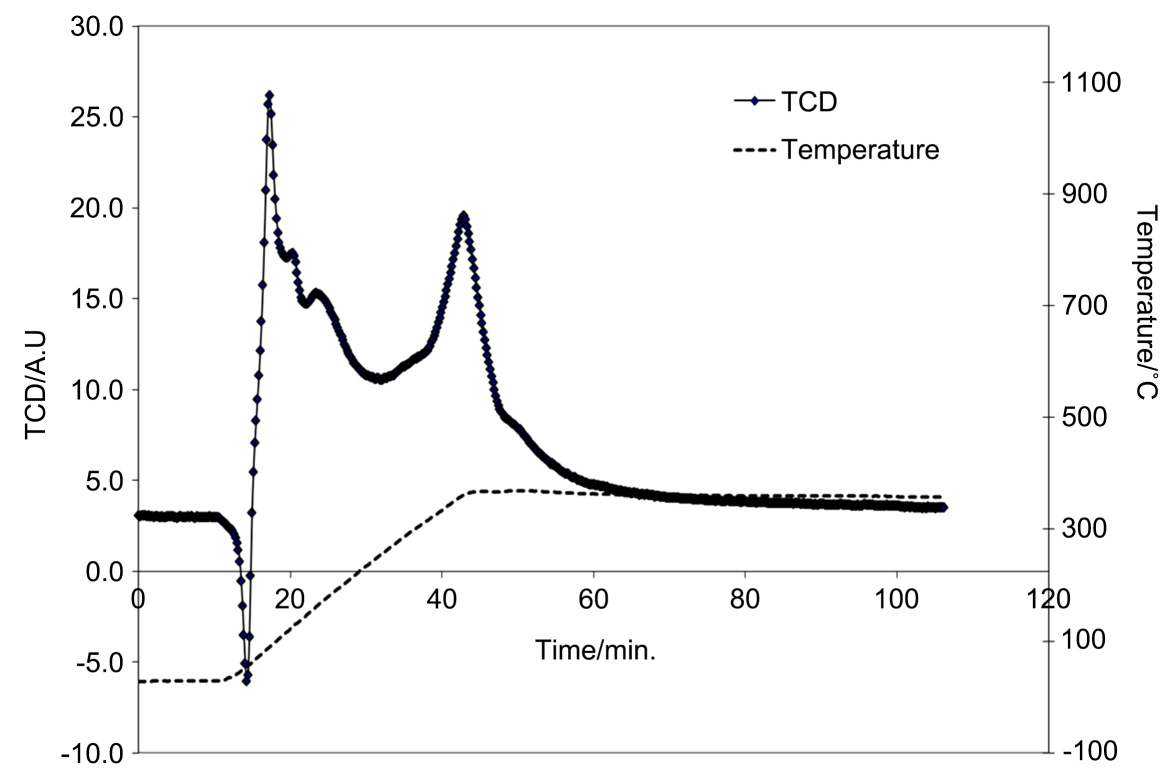

Figure 5. HTR of $\mathrm{Pd} / \mathrm{Sb}_{2} \mathrm{O}_{3} / \mathrm{Al}_{2} \mathrm{O}_{3}$.

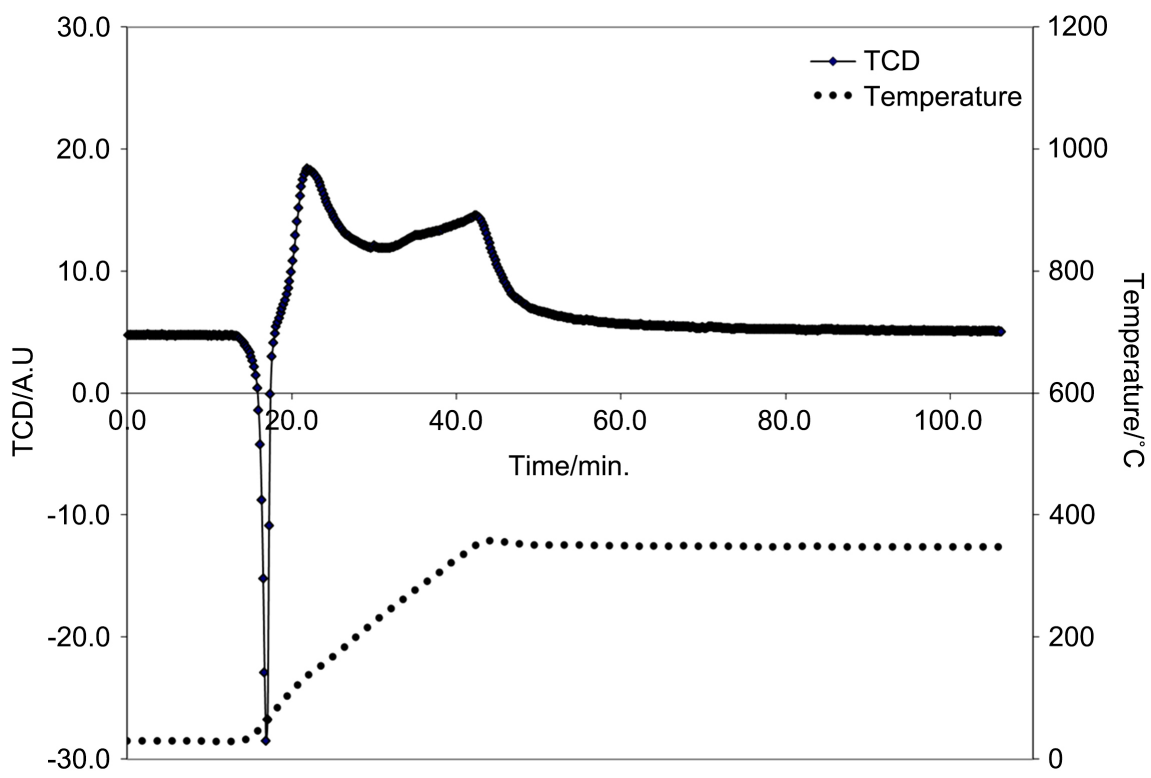

Figure 6. $\mathrm{HTR}$ of $\mathrm{Pd} / \mathrm{Sb}_{2} \mathrm{O}_{3} / \mathrm{ZrO}_{2}$. 


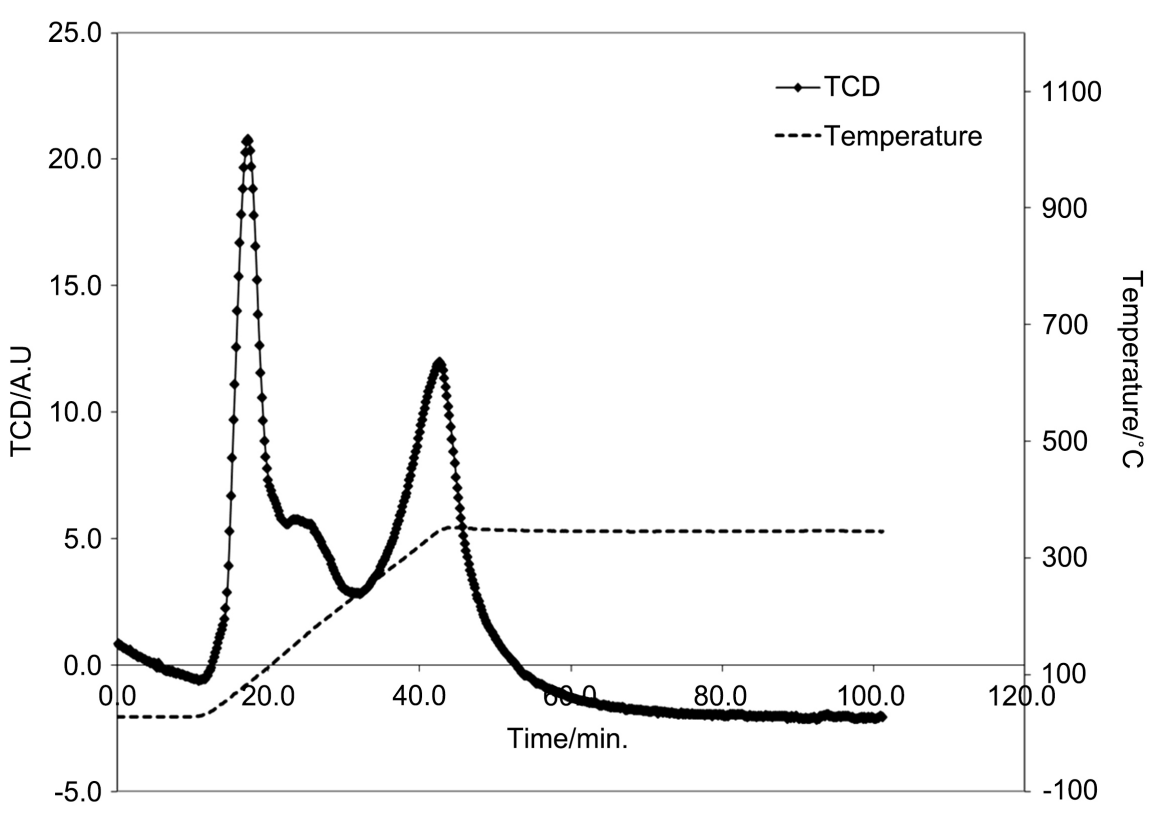

Figure 7. HTR of the catalyst $\mathrm{Pd} / \mathrm{Sb}_{2} \mathrm{O}_{3} / \mathrm{TiO}_{2}$.

From the literature relevant for the SMSI effect it can be concluded that $\mathrm{ZrO}_{2}$ and $\mathrm{TiO}_{2}$ are still not reduced at $350^{\circ} \mathrm{C}$ even in the presence of noble metals.

All three samples showed no $\mathrm{CO}$ consumption in the subsequent pulse chemisorption measurement. Obviously, $\mathrm{CO}$ chemisorption on $\mathrm{Pd}$ is completely suppressed by $\mathrm{SbO}_{\mathrm{x}}$ species by a typical SMSI effect as known for other reducible supports such as $\mathrm{TiO}_{2}, \mathrm{ZrO}_{2}, \mathrm{CeO}_{2}$ and $\mathrm{Nb}_{2} \mathrm{O}_{5}$ [40].

This conclusion was supported by an experiment to check the reversibility of the SMSI state. After the $\mathrm{CO}$ pulse measurement sample $\mathrm{Pd} / \mathrm{Sb}_{2} \mathrm{O}_{3} / \mathrm{ZrO}_{2}$ was oxidised by a TPO treatment up to $400^{\circ} \mathrm{C}$ ( $1 \mathrm{~h}$ hold at final temperature). Subsequently, it was reduced by a low temperature reduction (LTR) procedure up to $250^{\circ} \mathrm{C}$ only. Now, a significant $\mathrm{CO}$ adsorption could be stated.

In summary, the TPR studies revealed a close contact between the subsequently supported catalyst components $\mathrm{Sb}$ and $\mathrm{Pd}$, which result in an easier reducibility of $\mathrm{Sb}_{2} \mathrm{O}_{3}$. To prevent a reduction and/or migration of $\mathrm{SbO}_{\mathrm{x}}$ species onto the $\mathrm{Pd}$ particles (SMSI see below) we suggested limiting the reduction temperature to $250^{\circ} \mathrm{C}$. This temperature has to be also applied at least for elution of the TPR gas to obtain a hydrogen free Pd surface for a subsequent $\mathrm{CO}$ pulse chemisorption measurement.

\subsection{Low Temperature Reduction (LTR)}

TPR Plots for all catalysts are shown in Figures 8-10 and Figure 11. A partial reduction of $\mathrm{Sb}_{2} \mathrm{O}_{3}$ already at $250^{\circ} \mathrm{C}$ cannot be excluded because a clear separation between complete $\mathrm{Pd}(\mathrm{II})$ reduction and beginning $\mathrm{Sb}_{2} \mathrm{O}_{3}$ reduction which was not possible. Moreover, the long tailed profile during the isothermal segment points to reduction of a low amount of $\mathrm{Sb}_{2} \mathrm{O}_{3}$. However, we believe that 
$\mathrm{SbO}_{\mathrm{x}}$ species cannot migrate onto the Pd particles at $250^{\circ} \mathrm{C}$ because we obtained reasonable values for $\mathrm{CO}$ chemisorption.

At least the different $\mathrm{CO}$ chemisorption can be compared or related to properties of the various supports and to the catalytic activity. The results of the CO chemisorption measurements after LTR are summarised in Table 2. Most surprisingly, a very low $\mathrm{CO}$ chemisorption was reproducibly obtained with $\mathrm{Pd} / \mathrm{Sb}_{2} \mathrm{O}_{3} / \mathrm{TiO}_{2}$.

However, in case of large Pd particles also bridged bound CO (CO: Pd = 1/2) is present. Consequently dispersity and surface area could be up to twice and particle size up to a half of the values given in Table 2 .

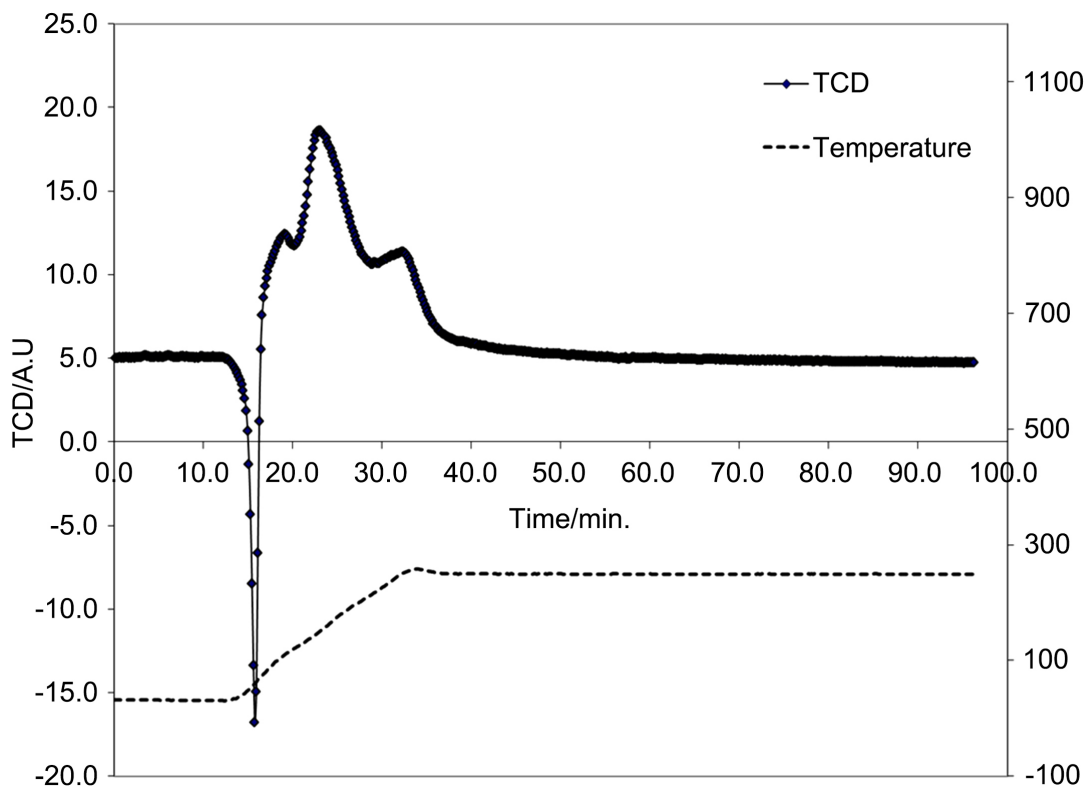

Figure 8. LTR of $\mathrm{Pd} / \mathrm{Sb}_{2} \mathrm{O}_{3} / \mathrm{ZrO}_{2}$.

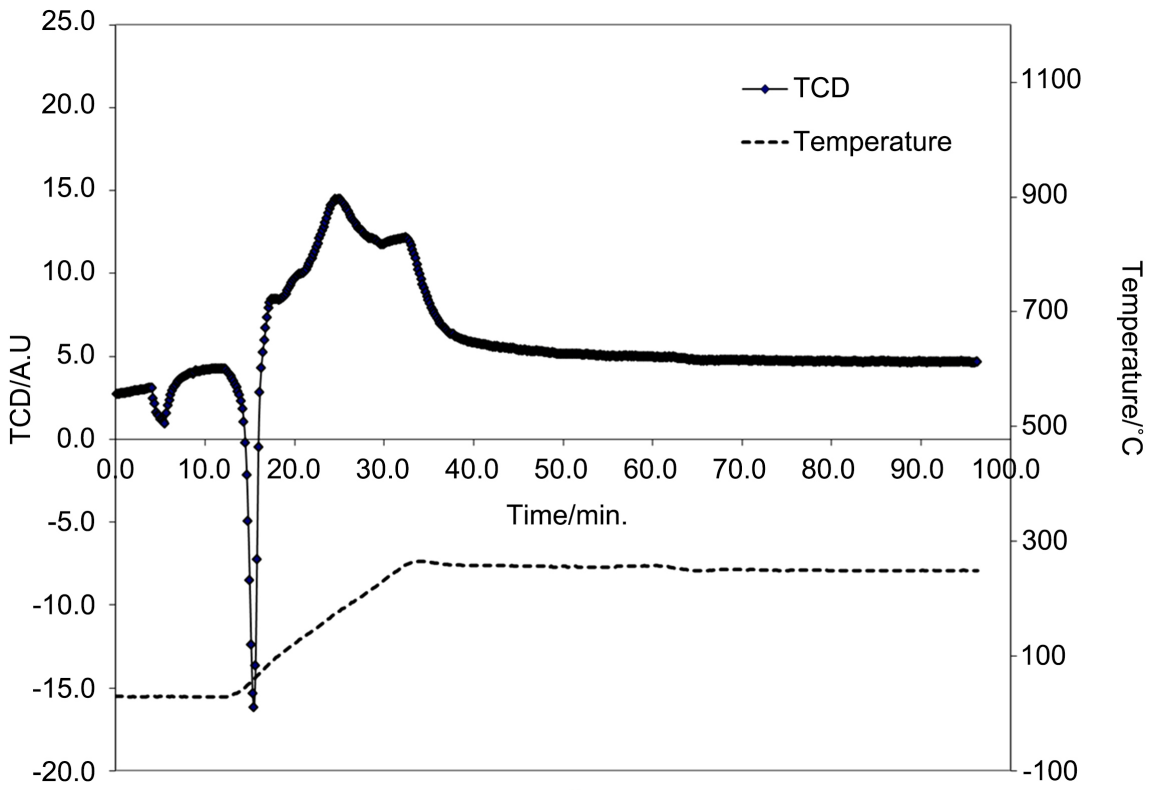

Figure 9. LTR of $\mathrm{Pd} / \mathrm{Sb}_{2} \mathrm{O}_{3} / \mathrm{Al}_{2} \mathrm{O}_{3}$. 


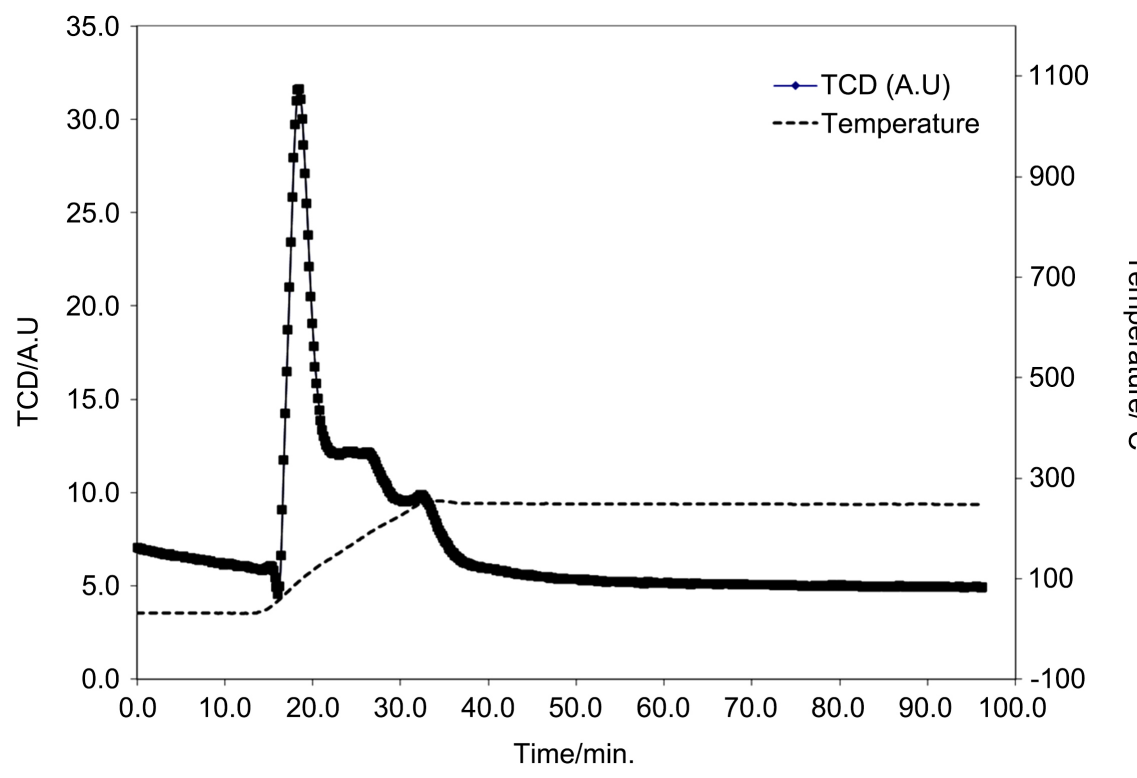

Figure 10. LTR of $\mathrm{Pd} / \mathrm{Sb}_{2} \mathrm{O}_{3} / \mathrm{TiO}_{2}$.

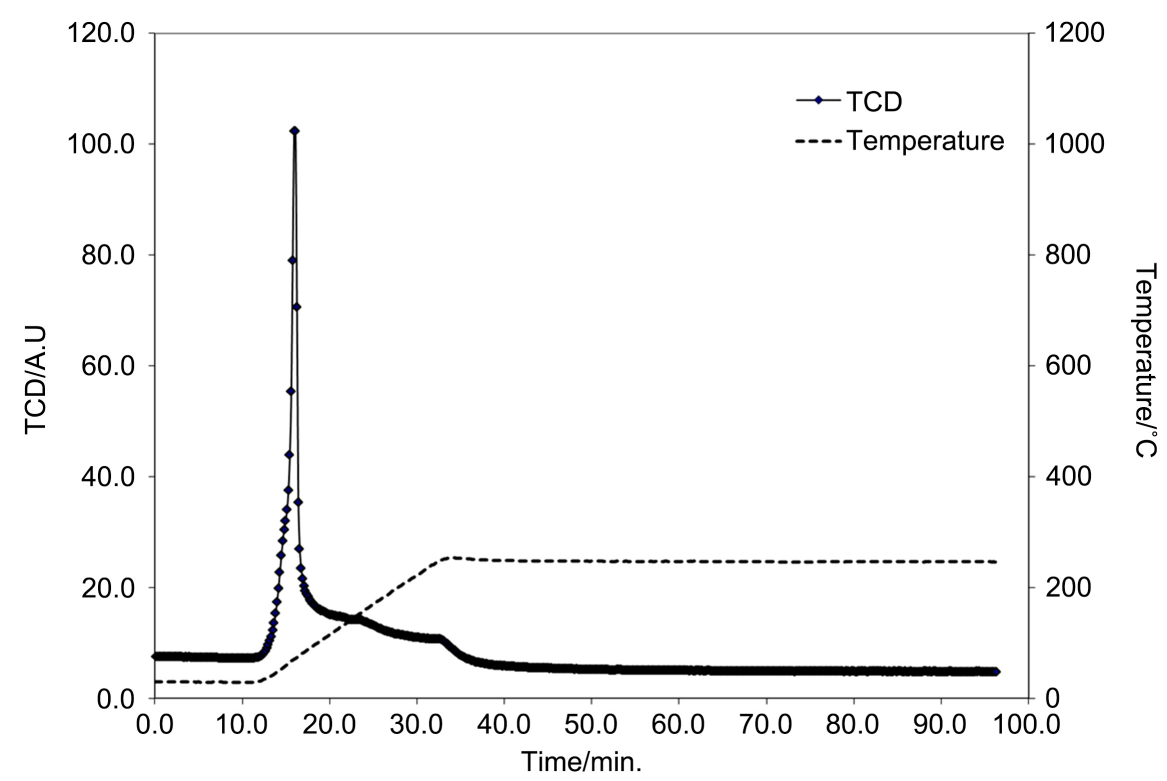

Figure 11. LTR of $\mathrm{Pd} / \mathrm{Sb}_{2} \mathrm{O}_{3} / \mathrm{SiO}_{2}$.

Table 2. CO Pulse Chemisorptions at r.t., LTR Pre-treatment.

\begin{tabular}{cccccc}
\hline Sample & $\begin{array}{c}\text { CO consumption } \\
\mu \mathrm{mol} / \mathrm{g} \\
\mathrm{red} .250^{\circ} \mathrm{C}\end{array}$ & $\begin{array}{c}\text { Dispersity* } \\
\%\end{array}$ & $\begin{array}{c}\text { Pd surface area } \\
\mathrm{m}^{2} / \mathrm{g}\end{array}$ & $\begin{array}{c}\mathrm{d}^{* *} \\
\mathrm{~nm}\end{array}$ & $\begin{array}{c}\mathrm{SBET} \\
\mathrm{m}^{2} / \mathrm{g}\end{array}$ \\
\hline $\mathrm{Pd} / \mathrm{Sb}_{2} \mathrm{O}_{3} / \mathrm{SiO}_{2}$ & 8.3 & 0.9 & 0.39 & 132 & 193 \\
$\mathrm{Pd} / \mathrm{Sb}_{2} \mathrm{O}_{3} / \mathrm{Al}_{2} \mathrm{O}_{3}$ & 14.4 & 1.5 & 0.68 & 76 & 97 \\
$\mathrm{Pd} / \mathrm{Sb}_{2} \mathrm{O}_{3} / \mathrm{ZrO}_{2}$ & $9.0 / 7.9$ & $1.0 / 0.8$ & 0.40 & 128 & 47 \\
$\mathrm{Pd} / \mathrm{Sb}_{2} \mathrm{O}_{3} / \mathrm{TiO}_{2}$ & $2.0 / 1.7$ & $0.21 / 0.18$ & 0.09 & 600 & 78 \\
\hline
\end{tabular}

${ }^{*}$ Assumption $10 \% \mathrm{Pd}, \mathrm{CO}: \mathrm{Pd}=1$ and using $1.27 \times 10^{15} \mathrm{Pd} / \mathrm{cm}^{2}$ (average face density); ${ }^{*}$ Assuming spherical Pd particles. 


$$
\begin{gathered}
\mathrm{S}_{\mathrm{Pd}}\left(\mathrm{cm}^{2} / \mathrm{g}\right)=\mathrm{CO}(\mu \mathrm{mol} / \mathrm{g}) \times 6 \times 10^{17} \mu \mathrm{mol}^{-1} / 1.27 \times 10^{15} \mathrm{Pd} \cdot \mathrm{cm}^{-2} \\
\mathrm{D}(\%)=\left(\mathrm{Pd}^{\mathrm{s}} / \mathrm{Pd}_{\mathrm{t}}\right) \times 100 \%=\left(\mathrm{CO} / \mathrm{Pd}_{\mathrm{t}}\right) \times 100 \% \\
\mathrm{~V}_{\mathrm{Pd}}=\mathrm{m}_{\mathrm{pd}} / \rho_{\mathrm{Pd}}=\mathrm{n} \times 4 \pi \mathrm{d}^{3}, \mathrm{~S}_{\mathrm{Pd}}=\mathrm{n} \times \pi \mathrm{d}^{2}, \mathrm{~V} / \mathrm{S}=\mathrm{d} / 6, \mathrm{~d}=6 \times \mathrm{m}_{\mathrm{pd}} /\left(\rho_{\mathrm{Pd}} \times \mathrm{S}\right)
\end{gathered}
$$

$\mathrm{n}$ : number of Pd-particles; $\mathrm{m}_{\mathrm{pd}}\left(\mathrm{mg}_{\mathrm{Pd}} / \mathrm{g}\right), \rho_{\mathrm{Pd}}=12 \mathrm{~g} / \mathrm{cm}^{3}$ volumic mass density Currently, the real Pd content (r\%Pd) of the samples is determined by ICP-OES. The result has to be considered to correct the values of the dispersity and particle size.

$$
\begin{aligned}
& \mathrm{D}_{\text {corr }}=\mathrm{D} \times 10 \% \mathrm{Pd} / \mathrm{r} \% \mathrm{Pd} \\
& \mathrm{d}_{\text {corr }}=\mathrm{d} \times \mathrm{r} \% \mathrm{Pd} / 10 \% \mathrm{Pd}
\end{aligned}
$$

Table 3 demonstrates the reversibility of the blocking of the CO chemisorption after HTR and subsequent TPO/LTR, respectively. This behaviour is written in the literature as typical for a SMSI effect [41]. TPO was performed up to $400^{\circ} \mathrm{C}$, subsequent reduction only up to $250^{\circ} \mathrm{C}$.

\section{Conclusions}

$\mathrm{SiO}_{2}$ supported $\mathrm{Pd}$ catalyst exhibited the highest surface area $192.6 \mathrm{~m}^{2} / \mathrm{g}$ and pore volume $0.542 \mathrm{~cm}^{3} / \mathrm{g}$ compared to the other supported oxides catalysts. The catalysts prepared with reducible supports $\left(\mathrm{TiO}_{2}, \mathrm{ZrO}_{2}\right)$ display low surface areas and showed a narrow distribution in the range of ca. 20 - $50 \AA$ with a dominant pore diameter around $35 \AA$. On the other hand, the catalysts with high surface areas $\left(\mathrm{SiO}_{2}, \gamma-\mathrm{Al}_{2} \mathrm{O}_{3}\right)$ displayed a considerably broader range of pore size distribution, from ca. 25 - $150 \AA$, with dominant pore diameters around $85 \AA\left(\mathrm{SiO}_{2}\right)$ and $60 \AA\left(\gamma-\mathrm{Al}_{2} \mathrm{O}_{3}\right)$, respectively. TEM images display a narrow size particle distribution of $\mathrm{Pd}$, but with varying sizes which in the range from 1 to $10 \mathrm{~nm}$, depending on the type of support used.

TPR studies confirmed a close neighbourhood between the catalysts components $\mathrm{Pd}$ and $\mathrm{Sb}$. The results show almost completely suppressed of CO chemisorption when the catalysts were subjected to High temperature reduction (HTR), this suppression was overcome by oxidation of a reduced $\mathrm{Pd} / \mathrm{MeOx}$ catalysts followed by re-reduction in hydrogen at $453 \mathrm{~K}$ (LTR), almost completely restored the normal chemisorptive properties of the samples, this suppression was attributed by SbOx species by a typical SMSI effect as known for other reducible supports such as $\mathrm{TiO}_{2}, \mathrm{ZrO}_{2}, \mathrm{CeO}_{2}$, and $\mathrm{Nb}_{2} \mathrm{O}_{5}$. We believe that this is the first report for such SMSI effect caused by the $\mathrm{Sb}_{2} \mathrm{O}_{3}$.

Table 3. CO Chemisorption after $\operatorname{HTR}\left(350^{\circ} \mathrm{C}\right)$ and TPO $\left(400^{\circ} \mathrm{C}\right) / \operatorname{LTR}\left(250^{\circ} \mathrm{C}\right)$.

\begin{tabular}{ccc}
\hline Sample & $\begin{array}{c}\text { CO consumption } \\
\mu \mathrm{mol} / \mathrm{g} \\
\text { after HTR }\end{array}$ & $\begin{array}{c}\text { CO consumption } \\
\mu \mathrm{mol} / \mathrm{g} \\
\text { after TPO/LTR }\end{array}$ \\
\hline $\mathrm{Pd} / \mathrm{Sb}_{2} \mathrm{O}_{3} / \mathrm{ZrO}_{2}$ & 0 & 20.1 \\
$\mathrm{Pd} / \mathrm{Sb}_{2} \mathrm{O}_{3} / \mathrm{TiO}_{2}$ & 0 & 13.4 \\
\hline
\end{tabular}




\section{Conflicts of Interest}

The authors declare no conflicts of interest regarding the publication of this paper.

\section{References}

[1] Tauster, S.J., Fung, S.C. and Garten, R.L. (1978) Strong Metal-Support Interactions. Group 8 Noble Metals Supported on Titanium Dioxide. Journal of the American Chemical Society, 100, 170-175. https://doi.org/10.1021/ja00469a029

[2] Tauster, S.J. (1987) Strong Metal-Support Interactions. Accounts of Chemical Research, 20, 389-394. https://doi.org/10.1021/ar00143a001

[3] Liu, J. (2011) Advanced Electron Microscopy of Metal-Support Interactions in Supported Metal Catalysts. Chem CatChem, 3, 934-948.

https://doi.org/10.1002/cctc.201100090

[4] Shi, X.Y., Zhang, W., Zhang, C., Zheng, W.T., Chen, H. and Qi, J.G. (2016) Real-Space Observation of Strong Metal-Support Interaction: State-of-the-Art and What's the Next. Journal of Microscopy, 262, 203-215. https://doi.org/10.1111/jmi.12366

[5] Bernal, S., Calvino, J.J., Cauqui, M.A., Gatica, J.M., Larese, C., Pérez Omil, J.A. and Pintado, J.M. (1999) Some Recent Results on Metal/Support Interaction Effects in $\mathrm{NM} / \mathrm{CeO}_{2}$ (NM: Noble Metal) Catalysts. Catalysis Today, 50, 175-206. https://doi.org/10.1016/S0920-5861(98)00503-3

[6] Qin, Z.-H., Lewandowski, M., Sun, Y.-N., Shaikhutdinov, S. and Freund, H.-J. (2008) Encapsulation of Pt Nanoparticles as a Result of Strong Metal-Support Interaction with $\mathrm{Fe}_{3} \mathrm{O}_{4}(111)$. The Journal of Physical Chemistry $C, 112,10209-10213$. https://doi.org/10.1021/jp801756q

[7] Haller, G.L. and Resasco, D.E. (1989) Metal-Support Interaction: Group VIII Metals and Reducible Oxides. In: Eley, D.D., Pines, H. and Weisz, P.B., Eds., Advances in Catalysis, Vol. 36, Academic Press, San Diego, 173-235.

https://doi.org/10.1016/S0360-0564(08)60018-8

[8] Bowker, M., Stone, P., Morrall, P., Smith, R., Bennett, R., Perkins, N., et al. (2005) Model Catalyst Studies of the Strong Metal-Support Interaction: Surface Structure Identified by STM on Pd Nanoparticles on $\mathrm{TiO}_{2}(110)$. Journal of Catalysis, 234, 172-181. https://doi.org/10.1016/j.jcat.2005.05.024

[9] Logan, A.D., Braunscheig, E.J., Datye, A.K. and Smith, D.J. (1989) Direct Observation of the Surfaces of Small Metal Crystallites: Rhodium Supported on Titania. Langmuir, 4, 827-830. https://doi.org/10.1021/la00082a009

[10] Freund, H.-J., Meijer, G., Scheffler, M., Schlögl, R. and Wolf, M. (2011) CO Oxidation as a Prototypical Reaction for Heterogeneous Processes. Angewandte Chemie International Edition, 50, 10064-10094. https://doi.org/10.1002/anie.201101378

[11] Resasco, D.E., Weber, R.S., Sakellson, S., McMillan, M. and Haller, G.L. (1988) X-Ray Absorption Near-Edge Structure Evidence for Direct Metal-Metal Bonding and Electron Transfer in Reduced Rhodium/Titania Catalysts. The Journal of Physical Chemistry, 92, 189-193. https://doi.org/10.1021/j100312a041

[12] Beard, B.C. and Ross, P.N. (1986) Platinum-Titanium Alloy Formation from HighTemperature Reduction of a Titania-Impregnated Platinum Catalyst: Implications for Strong Metal-Support Interaction. The Journal of Physical Chemistry, 90, 6811-6817. https://doi.org/10.1021/j100284a020 
[13] Vayenas, C.G., Brosda, S. and Pliangos, C. (2003) The Double-Layer Approach to Promotion, Electrocatalysis, Electrochemical Promotion, and Metal-Support Interactions. Journal of Catalysis, 216, 487-504. https://doi.org/10.1016/S0021-9517(02)00127-6

[14] Ioannides, T. and Verykios, X.E. (1996) Charge Transfer in Metal Catalysts Supported on Doped $\mathrm{TiO}_{2}$ : A Theoretical Approach Based on Metal-Semiconductor Contact Theory. Journal of Catalysis, 161, 560-569.

https://doi.org/10.1006/jcat.1996.0218

[15] Bernal, S., Botana, F.J., Calvino, J.J., Lopez, C., Perez-Omil, J.A. and Ro-driguezIzquierdo, J.M. (1996) High-Resolution Electron Microscopy Investigation of Metal-Support Interactions in $\mathrm{Rh} / \mathrm{TiO}_{2}$. Journal of the Chemical Society, Faraday Transactions, 92, 2799-2809. https://doi.org/10.1039/FT9969202799

[16] Dulub, O., Hebenstreit, W. and Diebold, U. (2000) Imaging Cluster Surfaces with Atomic Resolution: The Strong Metal-Support Interaction State of Pt Supported on $\mathrm{TiO}_{2}$ (110). Physical Review Letters, 84, 3646-3649. https://doi.org/10.1103/PhysRevLett.84.3646

[17] Bennett, R.A., Pang, C.L., Perkins, N., Smith, R.D., Morrall, P., Kvon, R.I. and Bowker, M. (2002) Surface Structures in the SMSI State; Pd on $(1 \times 2)$ Reconstructed $\mathrm{TiO}_{2}$ (110). The Journal of Physical Chemistry B, 106, 4688-4696. https://doi.org/10.1021/jp0138328

[18] Bennett, R.A., Stone, P. and Bowker, M. (1999) Pd Nanoparticle Enhanced Re-Oxidation of Non-Stoichiometric $\mathrm{TiO}_{2}$ : STM Imaging of Spillover and a New Form of SMSI. Catalysis Letters, 59, 99-105. https://doi.org/10.1023/A:1019053512230

[19] Pesty, F., Steinrück, H.-P. and Madey, T.E. (1995) Thermal Stability of Pt Films on $\mathrm{TiO}_{2}$ (110): Evidence for Encapsulation. Surface Science, 339, 83-95. https://doi.org/10.1016/0039-6028(95)00605-2

[20] Gao, Y., Liang, Y. and Chambers, S.A. (1996) Thermal Stability and the Role of Oxygen Vacancy Defects in Strong Metal Support Interaction Pt- on Nb-Doped $\mathrm{TiO}_{2}$ (100). Surface Science, 365, 638-648. https://doi.org/10.1016/0039-6028(96)00763-7

[21] Berkó, A., Ulrych, I. and Prince, K.C. (1998) Encapsulation of Rh Nanoparticles Supported on $\mathrm{TiO}_{2}(110)-(1 \times 1)$ Surface: XPS and STM Studies. The Journal of Physical Chemistry B, 102, 3379-3386. https://doi.org/10.1021/jp973255g

[22] Sadeghi, H.R. and Henrich, V.E. (1988) Electronic Interactions in the Rhodium/TiO System. Journal of Catalysis, 109, 1-11. https://doi.org/10.1016/0021-9517(88)90179-0

[23] Sadeghi, H.R. and Henrich, V.E. (1984) Rh on $\mathrm{TiO}_{2}$ : Model Catalyst Studies of the Strong Metal-Support Interaction. Applications of Surface Science, 19, 330-340. https://doi.org/10.1016/0378-5963(84)90070-9

[24] Labich, S., Taglauer, E. and Knözinger, H. (2000) Metal-Support Interactions on Rhodium Model Catalysts. Topics in Catalysis, 14, 153-161.

https://doi.org/10.1023/A:1009027621119

[25] Ruppert, A.M. and Paryjczak, T. (2007) $\mathrm{Pt} / \mathrm{ZrO}_{2} / \mathrm{TiO}_{2}$ Catalysts for Selective Hydrogenation of Crotonaldehyde: Tuning the SMSI Effect for Optimum Performance. Applied Catalysis A: General, 320, 80-90. https://doi.org/10.1016/j.apcata.2006.12.019

[26] Kudo, A. and Miseki, Y. (2009) Heterogeneous Photocatalyst Materials for Water Splitting. Chemical Society Reviews, 38, 253-278. https://doi.org/10.1039/B800489G 
[27] Linkous, C.A., Carter, G.J., Locuson, D.B., Ouellette, A.J., Slattery, D.K. and Smitha, L.A. (2000) Photocatalytic Inhibition of Algae Growth Using $\mathrm{TiO}_{2}, \mathrm{WO}_{3}$, and Cocatalyst Modifications. Environmental Science \& Technology, 34, 4754-4758. https://doi.org/10.1021/es001080+

[28] Liu, Y., Chen, L., Hu, J., Li, J. and Richards, R. (2010) $\mathrm{TiO}_{2}$ Nanoflakes Modified with Gold Nanoparticles as Photocatalysts with High Activity and Durability under near UV Irradiation. The Journal of Physical Chemistry C, 114, 1641-1645.

https://doi.org/10.1021/jp910500c

[29] Sakthivel, S., Shankar, M.V., Palanichamy, M., Arabindoo, B., Bahnemann, D.W. and Murugesan, V. (2004) Enhancement of Photocatalytic Activity by Metal Deposition: Characterisation and Photonic Efficiency of $\mathrm{Pt}, \mathrm{Au}$ and $\mathrm{Pd}$ Deposited on $\mathrm{TiO}_{2}$ Catalyst. Water Research, 38, 3001-3008. https://doi.org/10.1016/j.watres.2004.04.046

[30] Bayarri, B., Carbonell, E., Gimenez, J., Esplugas, S. and Garcia, H. (2008) Higher Intrinsic Photocatalytic Efficiency of 2,4,6-Triphenylpyrylium-Based Photocatalysts Compared to $\mathrm{TiO}_{2}$ P-25 for the Degradation of 2,4-Dichlorophenol Using Solar Simulated Light. Chemosphere, 72, 67-74.

https://doi.org/10.1016/j.chemosphere.2008.01.075

[31] da Silva, C.G. and Faria, J.L. (2003) Photochemical and Photocatalytic Degradation of an Azo Dye in Aqueous Solution by UV Irradiation. Journal of Photochemistry and Photobiology A: Chemistry, 155, 133-143. https://doi.org/10.1016/S1010-6030(02)00374-X

[32] Pan, C.-J., Tsai, M.-C., Su, W.-N., et al. (2017) Tuning/Exploiting Strong Metal-Support Heterogeneous Catalysis Heterogeneous Catalysis Interaction (SMSI) in Heterogeneous Catalysis. Journal of the Taiwan Institute of Chemical Engineers, 74, 154-186. https://doi.org/10.1016/j.jtice.2017.02.012

[33] Braunscheig, E.J., Logan, A.D., Datye, A.K. and Smith, D.J. (1989) Reversibility of Strong Metal-Support Interactions on $\mathrm{RhTiO}_{2}$. Journal of Catalysis, 118, 227-233. https://doi.org/10.1016/0021-9517(89)90313-8

[34] Hippe, C., Lamber, R., Schulz-Ekloff, G. and Schubert, U. (1997) Influence of the Strong-Metal Support Interaction on the CO Chemisorption at a $\mathrm{Pt} / \mathrm{SiO}_{2}$ Catalyst. Catalysis Letters, 43, 195-199. https://doi.org/10.1023/A:1018919412751

[35] Hicks, R.F., Yen, Q.-J. and Bell, A.T. (1984) Effects of Metal-Support Interactions on the Chemisorptions of $\mathrm{H}_{2}$ and $\mathrm{CO}$ on $\mathrm{PdSiO}_{2}$ and $\mathrm{PdLa}_{2} \mathrm{O}_{3}$. Journal of Catalysis, 89, 498-510. https://doi.org/10.1016/0021-9517(84)90326-9

[36] Benhmid, A., Narayana, K.V., Bischoff, S., Martin, A. and Lücke, B. (2005) Festphasen katalysator, Verfahren zu seiner Herstellung und seine Verwendung zur Herstellung von Arylestern. DE 102004002262 A1.

[37] Narayana Kalevaru, V., Benhmid, A., Radnik, J., Pohl, M.-M., Bentrup, U. and Martin, A. (2007) Marked Influence of Support on the Catalytic Performance of PdSb Acetoxylation Catalysts: Effects of Pd Particle Size, Valence States, and Acidity Characteristics. Journal of Catalysis, 246, 399-412. https://doi.org/10.1016/j.jcat.2007.01.002

[38] Shen, W.-J., Okumura, M., Matsumura, Y. and Haruta, M. (2001) The Influence of the Support on the Activity and Selectivity of Pd in CO Hydrogenation. Applied Catalysis $A, 213,225-232$. https://doi.org/10.1016/S0926-860X(01)00465-3

[39] Lyubovsky, M., Pfefferle, M., Datye, A., Bravo, J. and Nelson, T. (1999) TEM Study of the Microstructural Modifications of an Alumina-Supported Palladium Combustion Catalyst. Journal of Catalysis, 187, 275-284.

https://doi.org/10.1006/jcat.1999.2545 
[40] Burch, R. (1988) Strong Metal Support Interactions. In: Paal, Z. and Menon, P.G., Eds., Hydrogen Effects in Catalysis, Marcel Dekker, New York, 347.

[41] Anderson, J.B.F., Burch, R.R. and Cairns, J.A. (1986) The Influence of Metal-Support Interactions on the Reaction of n-Hexane over Supported Rh Catalysts. Applied Catalysis, 28, 255-269. https://doi.org/10.1016/S0166-9834(00)82509-9 